\title{
Cell cycle studies on the mode of action of yeast K28 killer toxin
}

\author{
Manfred J. Schmitt, ${ }^{1} \dagger$ Petra Klavehn, ${ }^{1}$ Jing Wang, ${ }^{2}$ Inge Schönig ${ }^{1}$ \\ and Donald J. Tipper ${ }^{2}$
}

Author for correspondence: Manfred J. Schmitt. Tel: +496813024730 . Fax: +496813024710.

\footnotetext{
1 Institut für Mikrobiologie und Weinforschung, Johannes GutenbergUniversităt Mainz, D-55099 Mainz, Germany

2 Department of Molecular Genetics and

Microbiology, University of Massachusetts Medical School, Worcester, MA 01655, USA
}

\begin{abstract}
The virally encoded K28 killer toxin of Saccharomyces cerevisiae kills sensitive cells by a receptor-mediated process. DNA synthesis is rapidly inhibited, cell viability is lost more slowly and cells eventually arrest, apparently in the 5 phase of the cell cycle with a medium-sized bud, a single nucleus in the mother cell and a pre-replicated (1n) DNA content. Cytoplasmic microtubules appear normal, and no spindle is detectable. Arrest of a sensitive haploid yeast strain by $\alpha$-factor at START gave complete protection for at least $4 \mathrm{~h}$ against a toxin concentration that killed non-arrested cells at the rate of one log each $2.5 \mathrm{~h}$. Cells released from $\alpha$-factor arrest were killed by toxin at a similar rate; arrest occurred with medium-sized buds within the same cell cycle. Cells arrested by hydroxyurea, with unreplicated DNA, or by the spindle poison methylbenzimidazol-2yl-carbamate, with unseparated chromosomes, both arrest at the checkpoint at the G2/M boundary; these arrested cells were not protected against toxin, losing about one log of viability every $4 \mathrm{~h}$. Following release from the cell cycle block, a majority of these toxin-exposed cells progressed through the cell cycle and arrested in the following S-phase, again with medium-sized buds. Killing by $\mathrm{K} 28$ toxin apparently requires entry into the nuclear division and bud cycles, but can result from inhibition of either early or late events in these cycles. Morphogenesis in moribund cells is uniformly blocked in early S-phase with an immature bud. Toxin action causes either independent blockage of both DNA synthesis and the budding cycle, or inhibits some unknown step required for both events.
\end{abstract}

Keywords: yeast, cell cycle, killer toxin, DNA synthesis

\section{INTRODUCTION}

Killer strains of the yeast Sacharomyces cervisiae sectete extracellular protein toxins encoded by cytoplasmic double-stranded RNA (M-dsRNA) viruses (Bussey, 1991 ; Wickner, 1992, 1993) of a type found in many fungal genera. Within the family of $S$, cerevisiae killer viruses only three have been clearly differentiated, the M1, M2 and M28 viruses, encoding the $\mathrm{K} 1, \mathrm{~K} 2$ and $\mathrm{K} 28$ toxins. Cells expressing each virus type are specifically resistant (immune) to their own toxin, but kill the other types. Strains lacking M-dsRNA viruses are killed by all three

\footnotetext{
†Present address: Institut für Mikrobiologie, Abteilung Angewandte Molekularbiologie, Universităt des Saarlandes, D-66041 Saarbrücken, Germany.

Abbreviations: FACS, fluorescence-activated cell sorting; HU, hydroxyurea; MBC, methylbenzimidazol-2yl-carbamate.
}

toxins (Schmitt \& Tipper, 1990; Tipper \& Schmitt, 1991). Sequence analysis of cDNA clones shows that each virus contains a single open reading frame encoding the preprotoxins M1p, M2p and M28p (Hanes et al., 1986; Schmitt, 1995; Schmitt \& Tipper, 1995). These preprotoxins lack sequence similarity either to each other or to other known genes. Expression of the preprotoxins from cDNA clones confers the same killer and immunity phenotypes expressed by the parent dsRNA viruses (Bostian et al., 1984; Dignard et al., 1991; Schmitt, 1995).

In the case of the $\mathrm{K} 1$ and $\mathrm{K} 28$ killer toxins, the biologically active and mature killer toxins are $\alpha / \beta$-heterodimeric proteins that kill sensitive yeast cells via a twostep receptor-mediated mechanism (Bostian et al., 1984; Schmitt \& Tipper, 1995). Less is known about the K2 toxin, although its mechanism is very similar to that of $\mathrm{K} 1$. In the first step, toxin binds to a cell wall receptor, a component of the $1,6-\beta$-D-glucan for the $\mathrm{K} 1$ and $K 2$ 


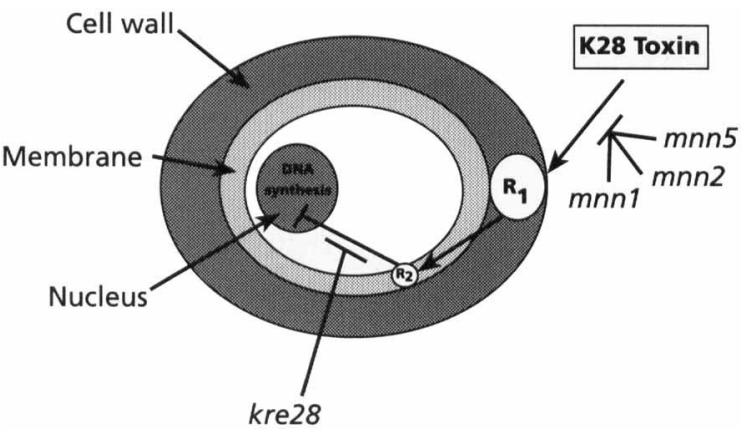

Fig. 1. Receptor-mediated killing of a sensitive yeast cell by killer toxin K28. Killing of a sensitive cell is envisaged as a twostage process involving initial binding of K28 toxin to the outer $1,3-\alpha$-mannotriose side-chains of a cell-wall mannoprotein $\left(R_{1}\right)$ dependent on the gene products of MNN1, MNN2 and MNN5. The toxin is thus accessible to the postulated plasma membrane receptor $\left(R_{2}\right)$, where it interacts with the cytoplasmic membrane. Interaction with this target is postulated to activate (through the action of Kre28p) a signal transduction pathway leading to inhibition of DNA synthesis. The potential mechanisms of toxin resistance are indicated by bars.

toxins and the outer 1,3- $\alpha$-linked mannose residues of cell wall mannoproteins in the case of K28 killer toxin (Hutchins \& Bussey, 1983; Schmitt \& Radler, 1988). Synthesis and assembly of these ptimary cell-wall binding sites requires a whole set of chromosomal $K R E$ and $M N N$ genes, the products of which are involved in glucan and mannoprotein synthesis, respectively (Bussey, 1991; Tipper \& Schmitt, 1991). Mutations within these nuclear genes lead to failure in cell-wall binding of toxin and a saturable resistance which is overcome at high toxin concentrations, suggesting that binding to the cell wall principally serves to concentrate toxin at the cell surface. Spheroplasts of sensitive cells are also sensitive to toxin and spheroplasts of kre or mnn mutants remain sensitive; spheroplasts of immune cells, however, express the same non-saturable resistance as their parent cells (Schmitt \& Radler, 1988). Sensitivity and immunity are, therefore, expressed at the plasma membrane, implying the existence of secondary membrane receptors whose occupancy initiates the second step in toxin action leading to cell death (Schmitt \& Compain, 1995).

Both $\mathrm{K} 1$ and $\mathrm{K} 2$ killer toxins exhibit their lethal effect on sensitive cells by disrupting cytoplasmic membrane function (Martinac et al., 1990). In contrast, K28 toxin has no such ionophoric effect but rather inhibits nuclear DNA synthesis (Fig. 1; Schmitt et al., 1989). We have previously shown that, following exposure to moderate concentrations of K28 toxin, the rate of viability loss in growing cells of the hypersensitive homothallic diploid strain 381 is quite low. Little cell death is detectable for $1-2 \mathrm{~h}$, after which one $\log$ of viability is lost each $4 \mathrm{~h}$, corresponding approximately to the inverse of the growth rate (Tipper \& Schmitt, 1991). In order to perform more incisive analyses of the effects of K28 toxin on the cell cycle, we constructed strain 4033, a $M A T a$ heterothallic derivative of strain 381 that retained its hypersensitivity. Cells that had been arrested in different stages of the cell cycle were exposed to more rapidly lethal concentrations of $\mathrm{K} 28$ toxin and phenotypes were determined following release from the cell cycle block in the continued presence or absence of toxin. We demonstrated that toxin-treated cells arrest in the budded phase of the cell cycle with an unteplicated (G1) content of DNA in a single nucleus located in the mother cell. While cells arrested with $\alpha$-factor at START were protected against toxin action, cells arrested at the G2/M checkpoint because of inhibition of DNA synthesis or microtubular function remained sensitive; following removal of the cell-cycle inhibitor, these moribund cells progressed through the cell cycle to arrest again in the following S-phase, even in the absence of additional toxin.

\section{METHODS}

General methods. Ali $S$. cerevisiae strains used in this work are described in Table 1. One hypersensitive haploid MATa strain, 4033, was used in the cell cycle studies described here. Strain 4033 represents a heterothailic $M A T a$ derivative of the homothallic ( $H O$ ) diploid, K28 hypersensitive strain 381, which was constructed by spore-to-cell matings essentially as described by Bakalinsky \& Snow (1990). Briefly, the heterothallic (bo) allele of the moderately $\mathrm{K} 28$ sensitive strain $7859-2-1 \mathrm{c}$ was introduced into strain 381 through spore-to-cell hybridization, resulting hybrids were sporulated, and heterothallic segregants were isolated for use in successive backcrosses. Heterothallic progeny of opposite mating type that retained their hypersensitivity against killer toxin K28 were isolated and further purified by repeated cycles of sporulation, ascus dissection, and clonal selection. Growth media and methylene biue agar (MBA) for killer assays were as described previously (Schmitt \& Tipper, 1990). Cell density and percentage of budded cells were monitored by fixing aliquots of culture samples in formaldehyde $(3.5 \%, v / v)$. Fixed cells were monitored with a phase-contrast microscope at $400 \times$ magnification. Cell viability was determined by plating culture samples on YEPD plates, buffered to $\mathrm{pH} 7.0$ with $50 \mathrm{mM} \mathrm{K}{ }_{2} \mathrm{HPO}_{4}$ at $30^{\circ} \mathrm{C}$. Under these conditions, killer toxin is rapidly inactivated.

Toxin production and killer assay. Cultures $(2 \times 10$ litres $)$ of the K28 superkiller strain MS300c (ski2-2; see Table 1) were grown for $5 \mathrm{~d}$ in synthetic $\mathrm{B}$-medium ( $\mathrm{pH} \mathrm{4.7).} \mathrm{Cells} \mathrm{were}$ harvested by centrifugation and the supernatant concentrated to a final volume of $20 \mathrm{ml}$ using ultrafiltration devices (Sartorius; Amicon) with YM10 membranes having a molecular mass cutoff of $10 \mathrm{kDa}$ (Schmitt \& Radler, 1987). Toxin was assayed by the quantitative well assay against a lawn of strain 381 , as previously described; $10^{4}$ units cortesponds to $1 \mu \mathrm{g}$ of purified toxin (Schmitt \& Tipper, 1995). Since the mature toxin has a molecular mass of approximately $21800 \mathrm{Da}$ (Schmitt \& Tipper, 1995 ), the standard concentration used in these studies, $2 \times 10^{6} \mathrm{U} \mathrm{ml}^{-1}$, is about $10 \mu \mathrm{M}$.

Cell cycle experiments. Cells of strain 4033, growing exponentialiy at $25^{\circ} \mathrm{C}$ in YEPD-citrate medium ( $\left.\mathrm{pH} 5 \cdot 0\right)$, were arrested at START by treatment with $\alpha$-factor at an initial concentration of $10^{-6} \mathrm{M}$, or at the transitional $\mathrm{G} 2 / \mathrm{M}$-phase by addition of the dTMP synthesis inhibitor hydroxyurea (HU; $0 \cdot 2 \mathrm{M}$ ) or the tubulin poison methylbenzimidazol-2yl-carbamate (MBC; $50 \mu \mathrm{g} \mathrm{ml}^{-1}$ ). Inhibitors were added at time zero and $\mathrm{K} 28$ toxin $\left(2 \times 10^{6} \mathrm{U} \mathrm{ml}^{-1}\right)$ was added to a sample at $5 \mathrm{~h}$. After further incubation for $2.5 \mathrm{~h}$ in the presence of inhibitors, with and without toxin, cells were pelleted by centrifugation and 
Table 1. Saccharomyces cerevisiae strains used

\begin{tabular}{|c|c|c|c|c|}
\hline Strain & Genotype & M28-dsRNA & Phenotype* & Source \\
\hline MS300c & MATa lew2 ura3-52 ski2-2 & + & $\mathrm{K}$ & Schmitt \& Tipper (1990) \\
\hline 381 & Diploid wild-type, homothallic & - & $\mathrm{S}$ & Schmitt \& Tipper (1990) \\
\hline $7859-2-1 c \dagger$ & $M A T \alpha$ rad9:: LEU2 ura 3 trp 1 leu 2 cyb 2 & - & $S$ & T'his work \\
\hline $4033+$ & 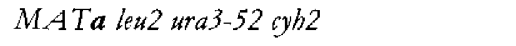 & - & $\mathrm{S}$ & This work \\
\hline F51 & $M A T \alpha$ lew 2 bis 3 arg 9 iup 1 & - & $S$ & Schmitt et al. (1989) \\
\hline
\end{tabular}

$* \mathrm{~K}$, K28 killer; S, sensitive.

† Strain 4033 is a heterothallic segregant from spore-to-cell mating of strain 381 with strain $7859-2-1 \mathrm{c}$, which is a heat-cured non-killer derivative of strain 7859-2-1 (Weinert \& Hartwell, 1990).

resuspended in an equal volume of fresh, pre-warmed YEPDcitrate medium ( $\mathrm{pH}$ 5.0) as previously described (Schmitt \& Radler, 1987), with and without toxin at the original concentration. Total cells, viable cells, and the percentage of budded cells were monitored for each culture sample as described above. Viability in toxin-treated cells was measured by plating at $\mathrm{pH} 7.0$ and $30^{\circ} \mathrm{C}$, conditions which rapidly inactivate any free toxin or toxin bound to the cell walls. All data were confirmed by repeating the experiments twice. Additional controls indicated that cells of strain 4033 treated with either $\mathrm{HU}$ or $\mathrm{MBC}$ for the duration of these experiments $(7.5 \mathrm{~h})$ remained fully viable.

Fluorescent antibody staining of microtubules. The procedure followed was essentially that described by Baum et al. (1988). Cells of strain 4033, following exposure to toxin in YEPD medium at $\mathrm{pH} 4.6$ and $23^{\circ} \mathrm{C}$, were fixed with $3.5 \%$ formaldehyde for $2 \mathrm{~h}$ in $20 \mathrm{mM} \mathrm{K}_{2} \mathrm{HPO}_{4}(\mathrm{pH} \mathrm{6.5)}$ and then washed five times in the same buffer containing $0.1 \%$ bovine serum albumin. Fixed cells were treated with $\beta$-metcaptoethanol $\left(2 \mu \mathrm{lml} l^{-1}\right)$ in the same buffer containing $1 \cdot 2 \mathrm{M}$ sorbitol, spheroplasted with zymolyase and mounted in wells of slides treated with poly(L-lysine) (Pringle et al,, 1991). Cells were incubated for $2 \mathrm{~h}$ with $5 \mu \mathrm{l}$ rat anti-yeast tubulin monoclonal antibody (YOL1/34), obtained from Accurate Chemical Co., diluted $1 / 100$ in $20 \mathrm{mM} \mathrm{K}_{2} \mathrm{HPO}_{4}(\mathrm{pH} \mathrm{6.5)}$ containing $0.1 \%$ bovine scrum albumin. After washing, bound antibody was detected by incubation with $5 \mu 11 / 100$ diluted FITC-labelled goat anti-rat $\operatorname{IgG}$ (Accurate Chemical Co.). Following staining with DAPI, cells were viewed using a Zeiss Axiophot epifluorescence microscope and appropriate filters. Colour negatives were scanned at high resolution and printed using a dye sublimation printer.

Fluorescence-activated cell sorting (FACS) analysis of cellular DNA content. Flow cytometry was performed on cells fixed in ethanol and stained with propidium iodide, essentially as described by Butler et al. (1991) and Murray \& Hunt (1993). Briefly, celis were grown in YEPD medium, exposed to toxin, collected by centrifugation and suspended in $70 \%(\mathrm{v} / \mathrm{v})$ ethanol. Celis were then washed in $20 \mathrm{mM}$ Tris $/ \mathrm{HCl}(\mathrm{pH} 7.5)$, treated with RNase A ( $2 \mathrm{mg} \mathrm{ml}^{-1}$ ) for $12 \mathrm{~h}$ at $37^{\circ} \mathrm{C}$, collected by centrifugation, and suspended in a freshly prepared pepsin solution $(0.5 \mathrm{M}$ pepsin in $50 \mathrm{mM} \mathrm{HCl})$ for $1.5 \mathrm{~h}$ at $37^{\circ} \mathrm{C}$, as described by Butler t t al. (1991). Cells were washed in $180 \mathrm{mM}$ Tris/ $\mathrm{HCl}(150 \mathrm{mM} \mathrm{NaCl}, 70 \mathrm{mM} \mathrm{MgCl} 2 ; \mathrm{pH} \mathrm{7.5})$ and stained in the same buffet containing propidium iodide $\left(50 \mu \mathrm{g} \mathrm{ml}^{-1}\right)$. Thereafter, samples were diluted 10 -fold in $50 \mathrm{mM}$ Tris $/ \mathrm{HCl}$ $(\mathrm{pH} 7.5)$ and analysed with an FACScan fluorescence-activated cell sorter (Becton-Dickinson). The propidium iodide was excited with a $15 \mathrm{mV}$ laser source at $488 \mathrm{~nm}$.

\section{RESULTS AND DISCUSSION}

\section{Mode of action of K28 toxin}

The K28 killer was originally identified in the homothallic diploid strain 28 of the strain collection of the Institut für Miktobiologie und Weinforschung, Johannes GutenbergUniversität, Mainz; another yeast in that collection, strain 381 , also a prototrophic homothallic diploid, was found to be hypersensitive to this toxin (Pfeiffer \& Radler, 1982). Common laboratory strains of $S$. cerevisiae either have much weaker sensitivity to K28 toxin or are resistant because of mnn mutations. To demonstrate inhibition of DNA synthesis directly, we used the K28sensitive strain F51, which is capable of taking up dTMP and is temperature-sensitive for dTMP synthesis. $\left[{ }^{3} \mathrm{H}\right] \mathrm{dTMP}$ incorporation at the restrictive temperature $\left(30^{\circ} \mathrm{C}\right)$ can be used to assay DNA synthesis in this strain. As shown in Fig. 2(b), addition of K28 toxin $\left(2 \times 10^{7} \mathrm{U}\right.$ $\mathrm{ml}^{-1}$ ) completely inhibited $\left[{ }^{3} \mathrm{H}\right] \mathrm{dTMP}$ incorporation within 30 min at $30^{\circ} \mathrm{C}$, at which time inhibition of neither RNA nor protein, synthesis was detectable (M. J. Schmitt $\&$ P. Klavehn, unpublished results). To demonstrate that K28 toxin inhibits DNA synthesis, and is not simply blocking dTMP transport, cells labelled with $\left[{ }^{3} \mathrm{H}\right] \mathrm{d}$ TMP at $30^{\circ} \mathrm{C}$ were incubated at the permissive temperature $\left(23^{\circ} \mathrm{C}\right)$. As shown in Fig. 2(c), the specific activity of DNA decreased in the control, due to new DNA synthesis, while the labelled DNA remained undiluted in toxin-treated cells.

Using the hypersensitive strain 381 , we previously showed that cells killed by $\mathrm{K} 28$ toxin arrest in the budded stage of the cell cycle with a single nucleus retained in the mother cell (Schmitt et al., 1989). The average bud size is approximately $20-30 \%$ of the mother cell volume. Because this morphology is not consistent with a simple inhibition of DNA synthesis, which causes cells to arrest at the $\mathrm{G} 2 / \mathrm{M}$ checkpoint with a large bud and the nucleus in the bud neck, we extended our previous findings by assessing, in a single strain (strain 4033), the DNA content, morphology and microtubular staining patterns of toxin-treated cells and by testing the toxin sensitivity of cells atrested at START or at the G2/M boundary of the yeast cell cycle.

Analysis of the effects of cell cycle inhibitors required the use of a heterothallic $M A T \boldsymbol{a}$ haploid. Because killing by 
(a)
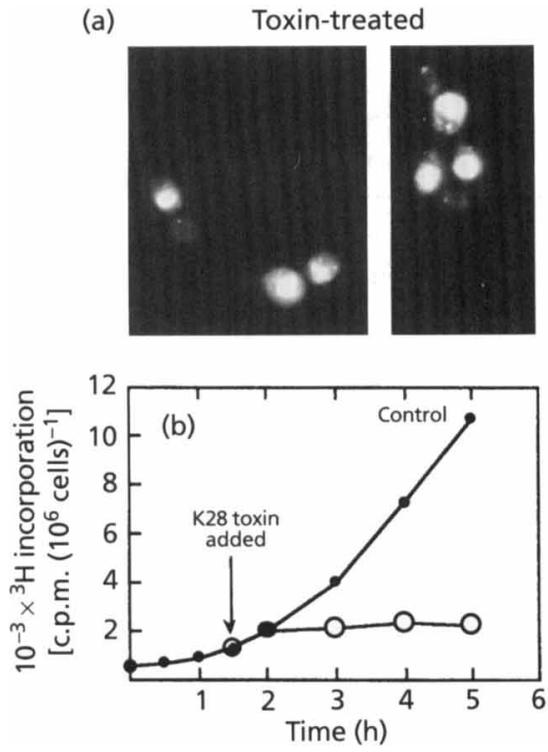
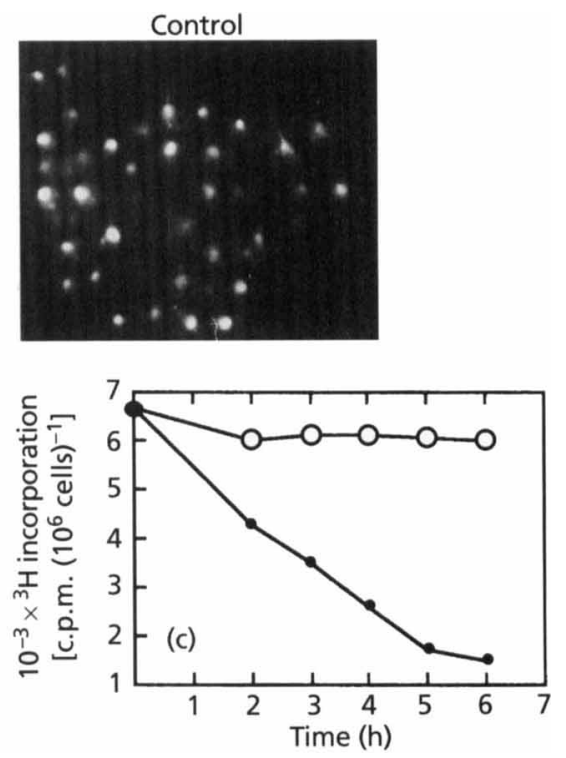

Fig. 2. (a) Fluorescence microscopy of K28 toxin-treated cells of strain 4033 visualized by DAPI staining. (b) Influence of killer toxin $\mathrm{K} 28$ on the incorporation of $\left[{ }^{3} \mathrm{H}\right] \mathrm{dTMP}$ into the DNA of S. cerevisiae strain F51. Cells of the sensitive ts-mutant strain F51 (grown at $36^{\circ} \mathrm{C}$ in the presence of $2 \times 10^{-5} \mathrm{M}$ dTMP) were adjusted to a concentration of $4.2 \times 10^{6}$ cells $\mathrm{ml}^{-1}$. The reaction was started by adding $20 \mu \mathrm{Ci} \quad(74 \mathrm{kBq}) \quad$ [methyl- ${ }^{3} \mathrm{H}$ ]dTMP [specific activity $40 \mathrm{Ci}(1480 \mathrm{GBq}) \mathrm{mmol}^{-1}$ ]. After incubating for $1.5 \mathrm{~h}$ at $30^{\circ} \mathrm{C}$, killer toxin $\mathrm{K} 28\left(2 \times 10^{7} \mathrm{U} \mathrm{ml}^{-1}\right)$ was added, samples $(1 \mathrm{ml})$ were withdrawn at the intervals indicated, and the radioactivity of the DNA was measured in a liquid scintillation system as previously described (Schmitt et al., 1989). (c) Inhibition of DNA synthesis in strain F51 by killer toxin K28. The DNA of strain $\mathrm{F} 51$ was radioactively labelled by growing the cells in the presence of $50 \mu \mathrm{Ci}(1850 \mathrm{kBq})\left[{ }^{3} \mathrm{H}\right] \mathrm{dTMP}$ for $24 \mathrm{~h}$ at $36^{\circ} \mathrm{C}$ with vigorous shaking. The labelled cells were centrifuged, washed three times with $1 \mathrm{ml}$ dTMP-free medium and incubated in the absence or presence of $K 28$ toxin $(0$. toxin-treated cells; 0 , control cultures; see text for details).
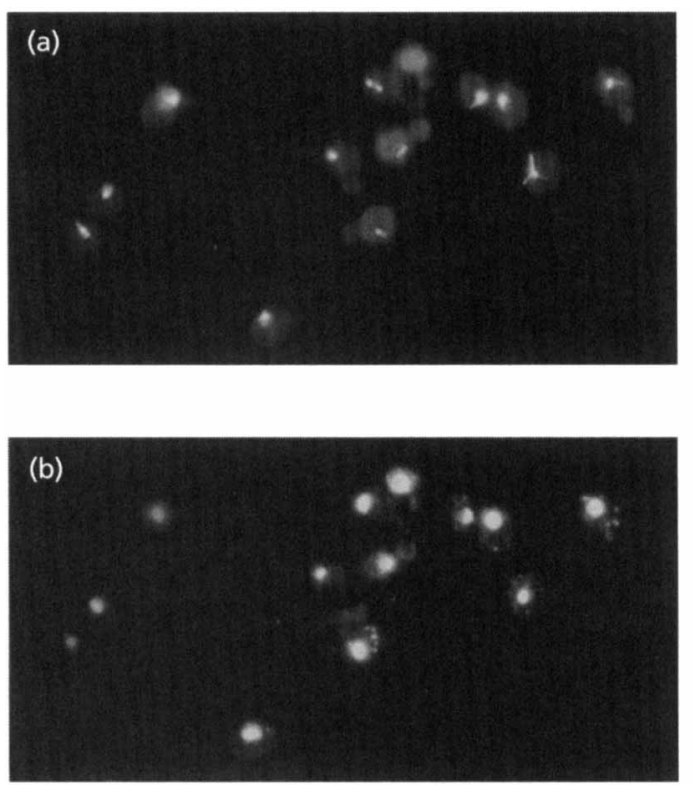

Fig. 3. Fluorescence microscopy of K28 toxin-treated cells of strain 4033 visualized by DAPI and by anti-tubulin staining. Toxin-treated, fixed cells of strain 4033 were either treated with rat anti-yeast tubulin monoclonal antibody and detected by incubation with FITC-labelled goat anti-rat $\lg G$ (a) or stained with DAPI (b) as described in Methods.

K28 toxin is fairly slow, even with the hypersensitive strain 381, this haploid needed to be of comparable hypersensitivity. Strain 4033 is a hypersensitive haploid segregant from a cross of strain 381 to a moderately sensitive laboratory strain. The effect of $\mathrm{K} 28$ toxin on cell viability in strain 4033 was strictly time- and dosedependent; at relatively high toxin concentrations $\left(2 \times 10^{6} \mathrm{U} \mathrm{m}^{-1}\right)$, one log of viability was lost every $3 \mathrm{~h}$ (Fig. 5a). Viability in toxin-treated cells was measured by plating at $\mathrm{pH} 7.0$ and $30^{\circ} \mathrm{C}$, conditions which rapidly inactivate any free toxin or toxin bound to the cell walls. Cell numbers reached a plateau after an increase of about $40 \%$, consistent with efficient inhibition of cell division within one cell cycle, and budded cells accumulated to more than $90 \%$ over $48 \mathrm{~h}$ (Fig. 5a). As shown in Fig. 2(a), cclls of strain 4033 treated with toxin for $8 \mathrm{~h}$ under these conditions arrested with a bud of intermediate size and the single nucleus was retained in the mother cell, confirming our previous observations in strain 381 (Schmitt et al., 1989). Microtubules were visualized by staining with anti-tubulin; staining was difficult in cells terminally arrested by $8 \mathrm{~h}$ exposure to toxin because of their extreme resistance to spheroplasting procedures. However, after $3 \mathrm{~h}$, most cells already had either small or medium-sized buds with single nuclei in the mother cell (Fig. 3b), and clear microtubular patterns were visible (Fig. 3a). The pattern of three radial microtubular bundles seen in one undivided cell shows that microscopic resolution was high. In the budded cells, tubulin seems to be restricted to one or two dots presumably corresponding to spindle pole bodies with, at most, a short cytoplasmic extension. No spindle is visible. It is clear, therefore, that nuclear spindle formation is inhibited.

If $\mathrm{K} 28$ toxin inhibits DNA synthesis while allowing cells to progress through the cell cycle, asynchronous exponential-phase cells exposed to toxin should accumulate with unreplicated DNA. We therefore measured DNA content in toxin-treated and untreated cells of strain 4033 by FACS analysis of cells stained with propidium iodide 


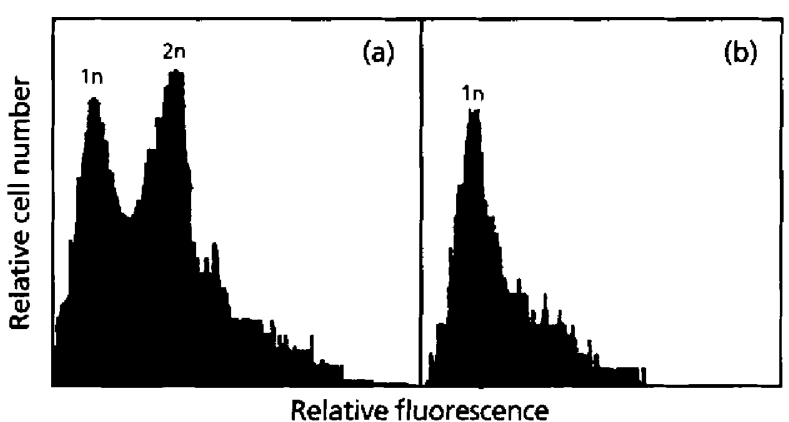

Fig. 4. FACScan analysis of DNA content of (a) control cells and (b) K28 toxin-treated cells of strain 4033, $6 \mathrm{~h}$ after toxin addition. Peaks corresponding to $1 \mathrm{n}$ and $2 \mathrm{n}$ DNA content are indicated.

(Fig. 4). Control cells in the absence of toxin showed the two peaks characteristic of a mixture of pre-S-phase cells having a single DNA content (1n) and post-S-phase cells having a DNA content of $2 n$, with the saddle representing cells in S (Fig. 4a). In contrast, cells treated with toxin for $6 \mathrm{~h}$ lacked the second ( $2 \mathrm{n})$ DNA peak, indicating that K28 toxin leads to an accumulation of yeast cells with unreplicated chromosomal DNA.

\section{Cells arrested by $\alpha$-factor are not killed by K28 toxin}

In order to map more precisely the point in the cell cycle at which $\mathrm{K} 28$ toxin exhibits its lethal effect, we used cells of strain 4033 that had been arrested at START in G1 by $\alpha$-factor treatment. We then added K28 toxin for several hours, and asked what happened to the cells after release from $\mathrm{G} 1$ arrest in the continued presence or absence of killer toxin. As shown in Fig. 5(b), cell division arrested within $2.5 \mathrm{~h}$ of addition of $\alpha$-factor, with a rapid drop in the proportion of budded cells. In the absence of toxin, when $\alpha$-factor was removed after $7.5 \mathrm{~h}$, cell growth recommenced at the original rate within $2 \mathrm{~h}$, and the percentage of budded cells increased to normal levels. When lethal concentrations of K28 toxin $\left(2 \times 10^{6} \mathrm{U} \mathrm{ml}^{-1}\right)$ were added to G1-arrested cells at $5 \mathrm{~h}$, cells remained fully viable until both $\alpha$-factor and toxin were removed at $7.5 \mathrm{~h}$ and were replaced by toxin alone (Fig. 5b). Viability then dropped as rapidly in cells released from $\alpha$-factor as in unarrested cells (Fig. 5a). Cell numbers remained constant, indicating toxin-induced arrest within the same cell cycle, and the proportion of budded cells increased over $6 \mathrm{~h}$ to about $75 \%$. These buds were of medium size with a single nucleus in the mother cell, like those shown in Fig. 2(a). This indicates that cells released from G1-arrest in the presence of toxin die after initiating S-phase and the bud cycle and adopt a terminal phenotype within that cycle. In additional experiments (data not shown), viability was maintained in the presence of both $\alpha$-factor and toxin for at least $4 \mathrm{~h}$, and the rate of viability loss after removal of $\alpha$-factor was similar even in the absence of additional toxin, demonstrating that $\alpha$-factor-arrested cells had already adsorbed lethal quantities of toxin. These data also demonstrate the efficacy of inactivation of bound toxin when cells are plated at $\mathrm{pH} 7 \cdot 0$ in the viability assay.

\section{Cells arrested by HU or MBC remain sensitive to $\mathrm{K} 28$ toxin}

The protection from toxin action afforded by G1 arrest indicates that cells must pass START to be killed, compatible with a primary effect on DNA synthesis. By testing the sensitivity of cells arrested at later stages in the cell cycle, we hoped to identify the execution point for lethality more precisely. Because of the temperature sensitivity of toxin, we were unable to use temperaturesensitive $c d c$ mutants and, instead, used metabolic inhibitors.

As shown in Fig. 5(c), cells of strain 4033 arrested in the budded portion of the cell cycle on addition of $\mathrm{HU}$; budded cells increased to $95 \%$, consistent with the known mode of action of HU as an inhibitor of dTMP synthesis. DNA elongation was inhibited and nuclear replication ceased; the budding cycle arrested in late G2, when the daughter cell was similar in size to the mother, due to activation of the G2/M checkpoint that monitors nuclear replication, and the nucleus traversed the bud neck with a completed spindle (data not shown). In the absence of toxin, on removal of $\mathrm{HU}$, cell division recommenced at the original rate with no detectable loss in viability and the proportion of budded cells fell back to normal levels (data not shown). However, if $\mathrm{K} 28$ toxin was added to $\mathrm{HU}$ arrested cells $2.5 \mathrm{~h}$ prior to HU removal, loss of viability commenced immediately and, on removal of HU, continued in the presence or absence of additional toxin. Since this continued loss in viability occurred in broth at $\mathrm{pH} 5$ but not in cells plated at $\mathrm{pH} 7$ in the viability assay, it must reflect the activity of toxin already bound to the cell wall. Most of these moribund cells divided after HU removal, and again adopted a terminal phenotype with a mediumsized bud and a nucleus in the mother cell (data not shown). The transient decrease in budded cells was only modest, probably reflecting asynchrony of cell division in these dying cells. Thus, HL-arrested cells suffer irreversible damage when exposed to K28 toxin and, following release from $\mathrm{HU}$ arrest, can proceed through $\mathrm{M}$ and $G 1$ phases, arresting again in the following S-phase.

MBC is a microtubule inhibitor that interferes with spindle function, so that cells arrest at the G2/M checkpoint for nuclear replication, as for $\mathrm{HL}$. However, the nuclear replication defect is in chromosomal segregation rather than in the earlier step of DNA synthesis. The results obtained with MBC-arrested yeast cells exactly reflected those obtained with HU-arrested cells (Fig. 5d). Ninety-five percent of $\mathrm{MBC}$-arrested cells accumulated with a large bud and all remained viable in the absence of toxin, so that normal cell division resumed on removal of MBC (data not shown). On addition of toxin to these MBC-arrested cells, loss of viability commenced immediately and continued to decline at $\mathrm{pH} 5$, following removal of $\mathrm{MBC}$ after an additional $2.5 \mathrm{~h}$, in the presence or absence of additional toxin. Again, the majority of cells 


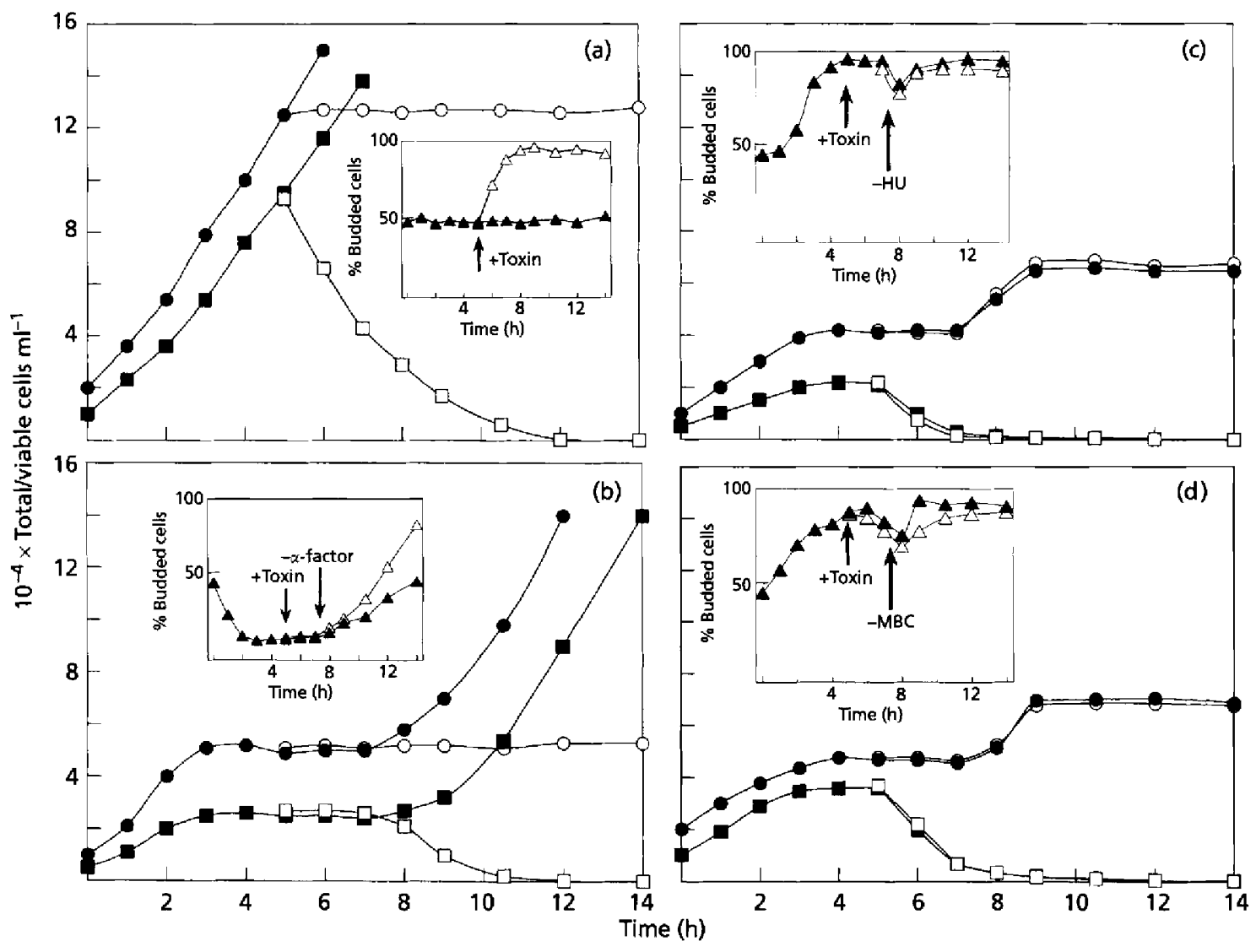

Fig. 5. Effects of $K 28$ toxin on sensitive cells of strain 4033 arrested in different phases of the yeast cell cycle. A culture of strain 4033, growing exponentially at $25^{\circ} \mathrm{C}$ in YEPD-citrate medium (pH 5.0), was divided in four at zero time. Culture (a) shows unarrested control cells; (b) cells arrested in $\mathrm{G} 1$ by addition of $10^{-6} \mathrm{M} x$-factor at zero time; (c) cells arrested in Sphase by treatment with $\mathrm{HU}(0.2 \mathrm{M})$ at zero time and (d), cells arrested in the transitional G2/M-phase by treatment at zero time with MBC, a tubulin poison $\left(50 \mu \mathrm{g} \mathrm{ml}^{-1}\right)$. (a) After $5 \mathrm{~h}$, the control culture was divided in two; one served as a toxin-free control $(0,0, \Delta)$ while $\mathrm{K} 28$ toxin $\left(2 \times 10^{6} \mathrm{U} \mathrm{ml}^{-1}\right)$ was added to the other $(O, \square, \Delta)$. Cultures were monitored throughout for total cells $(\boldsymbol{O})$, viable cells $(\boldsymbol{G})$ and the percentage of budded cells (inset; $\boldsymbol{\Delta}, \Delta$ ). Viability was measured by plating at $\mathrm{pH} 7.0$ and $30^{\circ} \mathrm{C}$, conditions which rapidly inactivate any toxin bound to the walls, so reflects only lethal events prior to plating. (b) After $5 \mathrm{~h}$, the $\alpha$-factor arrested culture was divided in two; one served as a toxin-free control (-,$\Delta$ ) while $\mathrm{K} 28$ toxin $\left(2 \times 10^{5} \mathrm{U} \mathrm{ml}^{-1}\right)$ was added to the other $(0, \square, \Delta)$. At $7.5 \mathrm{~h}$, cells of both cultures were washed free of $\alpha$-factor and toxin by centrifugation, and resuspended in an equal volume of fresh, pre-warmed YEPD-citrate

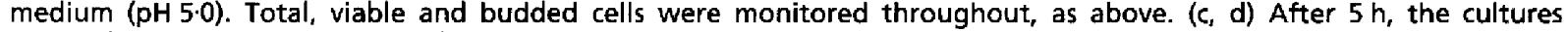
arrested with $\mathrm{HU}$ or MBC were divided in three; one served as a toxin-free control (data not shown) while K28 toxin $\left(2 \times 10^{6} \mathrm{U} \mathrm{ml}^{-1}\right)$ was added to the other two. These two cultures were monitored independently for total, viable and budded cells. At $7.5 \mathrm{~h}$, cells of both pairs of cultures were washed free of inhibitory drug and toxin, and resuspended in an equal volume of fresh, pre-warmed YEPD-citrate medium $(\mathrm{pH} \mathbf{5} \mathbf{0})$. One culture $(\mathbf{O}, \mathbf{D}, \mathbf{A})$ was incubated without additional toxin, so that additional viability loss reflects the action of pre-bound toxin, and the other after addition of toxin $\left(2 \times 10^{6} \mathrm{U} \mathrm{ml}^{-1} ; 0, \square, \triangle\right)$.

divided and arrested with the characteristic S-phase morphology.

\section{Model for K28 toxin action within the yeast cell cycle}

Although it is clear that cells arrested at START by $\alpha$ factor are protected from toxin action, while cells arrested by $\mathrm{HU}$ or $\mathrm{MBC}$ are not, it is difficult to identify the precise execution point, the stage of the yeast cell cycle that is most critical for K28 toxin action (Fig. 6). It appears that cells must have initiated DNA replication and the bud cycle to be susceptible, and lose susceptibility in mitosis. However, K28 toxin can cause irreversible damage in early stages of the budding cycle, in cells released from $\alpha$ factor arrest, and in cells arrested late in the nuclear and budding cycle at the $\mathrm{G} 2 / \mathrm{M}$ checkpoint. In each case, toxin eventually induces arrest with medium-sized buds and a single nucleus in the mother cell. However, this occurs in the same cycle in G1/S-arrested cells but after passing through mitosis and $\mathrm{G} 1$ in $\mathrm{G} 2 / \mathrm{M}$-arrested cells. In both cases, cells reach their terminal phenotype after initiating DNA synthesis, a potential common execution point, but any toxin-induced lethality is irreversibly induced in cells arrested at the prior G2/M checkpoint by inhibition of either DNA replication or spindle function. The observed relatively rapid and initially reversible 


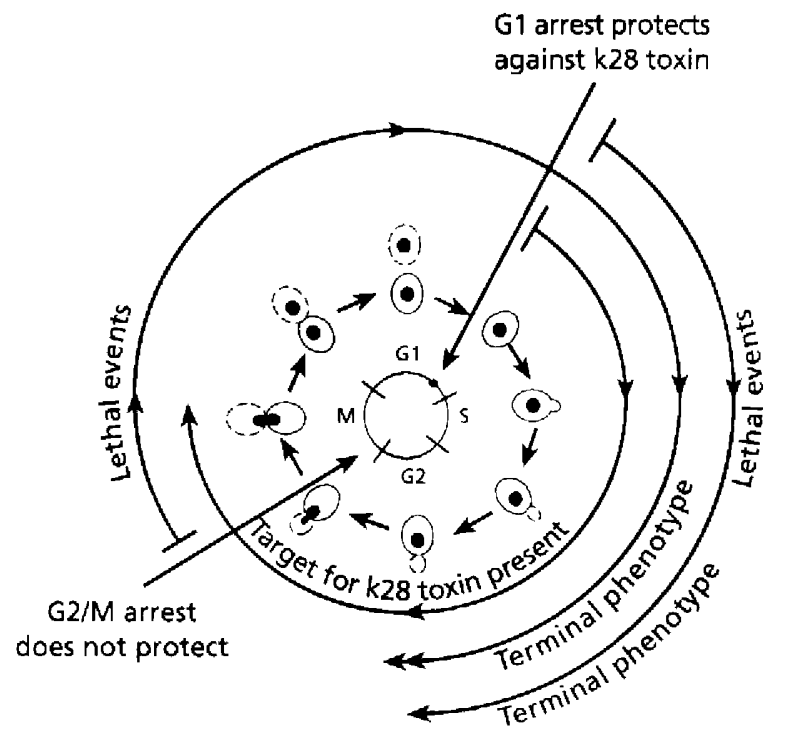

Fig. 6. Model for the primary target of the viral K28 killer toxin within the yeast cell cycle (see text for details).

inhibition of DNA synthesis could reflect inhibition of some separate event, or could reflect inhibition of some unknown event common to DNA replication and completion of the bud cycle.

The mode of action of $\mathrm{K} 28$ toxin appears to be unique, unlike that of other known yeast and fungal killer toxins. Clarification of the model shown in Fig. 1 requires identification of the primary toxin target. We hope to achieve this by analysis of resistant mutants. However, the great majority of $S$. cerevisiae mutants selected for resistance to K 28 toxin are alleles of either $m n n 1, m n n 2$ or $m n n 5$, whose products are involved in cell-wall mannoprotein side-chain synthesis (Schmitt \& Radler, 1988). Analysis of mutants which are toxin-resistant as spheroplasts should be more informative. The kre 28 mutant is such a mutant, whose gene product, Kre28p, might be involved in the unidentified signal transduction pathway leading to the observed inhibition of DNA synthesis and morphological effects (M. J. Schmitt \& D. J. Tipper, unpublished results; see Fig. 1).

Yeast gene products known to be involved in controlling the initiation of DNA synthesis include the singlestranded DNA-binding protein and the Pol $\alpha$-primase complex, both of which are modulated by phosphorylation and dephosphorylation events carried out by different protein kinases and phosphatases, prcsumably including the Cdc7p kinase (Foiani et al., 1995). Since the $B$ subunit of the yeast Pol $\alpha$-primase complex was recently shown to execute an essential role at the initial stage of DNA synthesis before the HU-sensitive step (Foiani et al., $1994)$, it would be interesting to test these $\alpha$-primase complex mutants for $\mathrm{K} 28$ toxin sensitivity, to determine if lethality requires exccution of their function. Detailed analysis of $\mathrm{K} 28$ toxin action may uncover novel aspects of control of the mitotic cell cycle in yeast, potentially conserved in higher eukaryotes.

\section{ACKNOWLEDGEMENTS}

We thank Claudia Darmstadt for technical assistance, and Robert K. Mortimer tor the generous gift of the tubulin poison MBC. This work was kindly supported by grant Schm 541/3-3 from the Deutsche Forschungsgemeinschaft to M. J.S. and by grant VM80 from the Ametican Cancer Society to D. J.T.

\section{REFERENCES}

Bakalinsky, A. T. \& Snow, R. (1990). Conversion of wine strains of Sacharomyces cerevisiae to heterothallism. Appl Emiron Microbiol 56, 849857.

Baum, P., Yip, C., Goetsch, L. \& Byers, B. (1988). A yeast gene essential for regulation of spindle pole duplication. Mol Cell Biol 8, 5386-5397.

Bostian, K. A.r Elliot, Q., Bussey, H., Burn, V., Smith, A. \& Tipper, D. J. (1984). Sequence of the preprotoxin dsRNA gene of type 1 killer yeast: multiple processing events produce a two component toxin. Cell 36, 741-751.

Bussey, H. (1991). K1 killer toxin: a pore-forming protein from veast. Mol Microbiol 5, 2339-2343.

Butler, A. R., White, J. H. \& Stark, M. J. R. (1991). Analysis of the response of Saccharomyces cerevisiae cells to Klyyeromyces lactis toxin. J Gen Microbiol 137, 1749-1757.

Dignard, D., Whiteway, M., Germain, D., Tessier, D. \& Thomas, D. Y. (1991). Expression in yeast of a cDNA copy of the K2 killer toxin gene. Mol Gen Genet 227, 127-136.

Foiani, M., Marini, F., Gamba, D., Lucchini, G. \& Plevani, P. (1994). The $\mathrm{B}$ subunit of the DNA polymerase $\alpha$-primase complex in Saccbaromyces cerevisiae executes an essential function at the initial stage of DNA replication. Mol Cell Biol 14, 923933.

Foiani, M., Liberi, G., Lucchini, G. \& Plevani, P. (1995). Cell cycledependent phosphorylation and dephosphorylation of the yeast DNA polymerase $\alpha$-primase B subunit. Mol Cell Biol 15, 883-891.

Hanes, S. D., Burn, V. E., Sturley, S. L., Tipper, D. J. \& Bostian, K. A. (1986). Expression of a cDNA derived from the yeast killer preprotoxin gene: implications for processing and immunity. Proc Natl Acad Sci USA 83, 1675-1679

Hutchins, K. \& Bussey, H. (1983). Cell wall receptor of ycast killer toxin: involvement of 1,6- $\beta$-D-glucan. J Batteriol 154, 161-169.

Martinac, B., Zhu, H., Kubalski, A., Zhou, X., Culbertson, M., Bussey, H. \& King, C. (1990). Yeast K1 killer toxin forms ion channels in sensitive ycast spheroplasts and in artificial liposomes. Proc Nati Acad Soi LS A 87, 6228-6232.

Murray, A. W. \& Hunt, T. (1993), The Cell Cycle. New York: W. H. Freeman.

Pfeiffer, P. \& Radler, F. (1982). Purification and characterization of extracellular and intracellular killer toxin of Sacharamyces cerevisiae strain 28. J Gen Microbiol 128, 2699-2706.

Pringle, J. R., Preston, R. A., Adams, A. E. M., Haarer, B. K. \& Jones, E. W. (1991). Immunofluorescence methods for yeast. Metbods Enqymol 194, 565-602.

Schmitt, M. J. (1995). Cloning and expression of a cDNA copy of the viral K28 killer toxin gene in yeast. Mol Gen Genet 246, 236-246. 
Schmitt, M. J. \& Compain, P. (1995). Killer toxin resistant kre 12 mutants of Sacharomyces cerevisiae : genetic and biochemical evidence for a secondary K1 membrane receptor. Arch Micrabiol 164, 435-443.

Schmitt, M. J. \& Radler, F. (1987). Mannoptotein of the yeast cell wall as primary receptor for the killer toxin of Sacharomyces cereviside strain 28. J Gen Microbiol 133, 3347-3354.

Schmitt, M. J. \& Radler, F. (1988). Molecular structure of the cell wall receptor for killer toxin K28 in Saccbaromyces cerevisiae. J Bacteriol 170, 2192-2196.

Schmitt, M. J. \& Tipper, D. J. (1990). K28, a unique doublestranded RNA killer virus of Saccharomyces cerevisiae. Mol Cell Biol $10,4807-4815$.

Schmitt, M. J. \& Tipper, D. J. (1995). Sequence of the M28-dsRNA: preprotoxin is processed to an $\alpha / \beta$-heterodimetic protein toxin. Virology 213, 341-351.
Schmitt, M. J., Brendel, M., Schwarz, R. \& Radler, F. (1989). Inhibition of DNA synthesis in Saccharomyces cerevisiae by yeast killer toxin K28. J Gen Microbiol 135, 1529-1535.

Tipper, D. J. \& Schmitt, M. J. (1991). Yeast dsRNA viruses: replication and killer phenotypes. Mol Microbiol 5, 2331-2338.

Weinert, T. A., \& Hartwell, L. H. (1990). Characterization of $R A D 9$ of Saccharomyces cerevisiae and evidence that its function acts posttranslationally in cell cycle arrest after DNA damage. $\mathrm{Mo} / \mathrm{Cell}$ Biol 10, 65546564.

Wickner, R. B. (1992). Double-stranded and single-stranded RNA viruses of Saccbaromyces cerevisiae. Annu Rev Microbiol 46, 347-375.

Wickner, R. B. (1993). Double-stranded RNA virus replication and packaging. J Biol Chem 268, 3797-3800.

Received 13 December 1995; revised 28 March 1996; accepted 10 April 1996. 